\title{
DINAMIKA PENGARUSUTAMAAN MODERASI ISLAM DI MASJID NASIONAL AL-AKBAR SURABAYA (MAS)
}

\author{
Muktafi \\ Universitas Islam Negeri Sunan Ampel Surabaya, Indonesia \\ E-mail: muktafi@uinsby.ac.id
}

\begin{abstract}
This article discusses the dynamics of mainstreaming Moderate Islam in the Masjid Nasional Al-Akbar Surabaya (MAS) by analyzing how the design of Islamic moderation developed by MAS managers. This article also analyzes the sermon material delivered by the preachers during a khutbah on Friday can have an impact on mainstreaming moderate Islam. The construction of Moderate Islam at the MAS is Islam rahmah li al-álamin by carrying out and upholding five basic principles, namely: tawāsut, tawāaun, ta'ädul, tasämuh, and amr ma'rüf wa naby 'an al-munkar bi al-ma'rüf. The dynamics of mainstreaming Moderate Islam carried out by MAS is with the strategy of escorting $d a^{\prime} w a h$ starting from choosing khotib/dai, determining the themes of Islam that give mercy to all humans by upholding al-akbläq alkarimah according to MAS's vision, mission and value by putting forward mandate, istikamah, giving uswah, being responsible, and li jamí al-ummah).
\end{abstract}

Keywords: Masjid Nasional Al-Akbar Surabaya; Moderate Islam.

\begin{abstract}
Abstrak: Artikel ini mendiskusikan dinamika pengarusutamaan Islam Moderat di Masjid Nasional Al-Akbar Surabaya (MAS) dengan menganalisis bagaimana design moderasi Islam yang dikembangkan oleh para pengelola Masjid Nasional Al-Akbar Surabaya. Artikel ini juga menganalisis sejauh mana materi-materi khutbah yang disampaikan oleh para dai saat khutbah Jumat bisa memberi dampak pada upaya pengarusutamakan Islam moderat. Konstruksi Islam Moderat di MAS adalah Islam rạ̣mah li al-'älamin dengan mengusung dan menjunjung lima prinsip dasar, yaitu: tawāsut, tawāzun, ta'ādul, tasāmuḥ, dan ber-amr ma'rüf wa naby 'an al-munkar bi al-ma'rüf. Dinamika pengarusutamaan Islam Moderat yang dilakukan oleh MAS adalah dengan strategi mengawal dakwah mulai dari memilih khotib/dai, menentukan tema-tema Islam yang memberikan rahmat pada seluruh manusia dengan menjunjung tinggi al-akhläq al-karimah sesuai visi, misi, dan nilai MAS dengan mengedepankan sikap amanah, istikamah, memberikan uswah, bertanggung jawab, dan li jamí al-ummah).
\end{abstract}

Kata Kunci: Masjid Nasional Al-Akbar Surabaya; Islam Moderat. 


\section{Pendahuluan}

Gerakan kelompok Salafi di beberapa dasawarsa ini telah berupaya menumbuhkembangkan ideologi salafisme di masjid-masjid yang secara umum di bawah koordinasi kelompok Nahdlatul Ulama dan Muhammadiyah, di mana kedua kelompok ini dianggap sebagai kelompok yang pro-demokrasi dan sangat moderat. ${ }^{1}$ Muslim puris atau radikal biasanya menjadikan masjid, musalla, kampus, dan koskosan mahasiswa sebagai titik pijak pergerakan sejumlah organisasi Islam yang fundamentalis. Tempat-tempat tersebut menjadi tempat indoktrinasi, perekrutan, dan cuci otak melalui program ḥaläqah, usrah, dan dawrah. ${ }^{2}$

Lingkup materi ceramah dan khutbah terkadang mengarah kepada hate speech. Misalnya riset yang ditulis oleh Zakiyuddin Baidhawy tentang "Muatan Nilai-nilai Multikultural dan Anti-Multikultural dari Mimbar Masjid di Kota Solo". Penelitian ini bertujuan untuk mengidentifikasi lingkup materi ceramah dan khotbah di masjidmasjid dan majelis taklim di Solo, dan mengidentifikasi aspek-aspek multikultural dan anti-multikultural yang disampaikan dalam khotbah dan ceramah. Studi ini menyimpulkan: Pertama, keragaman masyarakat — etnis, budaya, atau agama - mendapat sedikit perhatian dari pengkhotbah di berbagai masjid dan majelis taklim. Kedua, di samping nilai-nilai multikultural, khotbah dan ceramah keagamaan berisi beberapa nilai-nilai anti-multikultural, seperti prasangka dan stereotip terhadap kelompok lain, khususnya dalam hubungan dengan non-Muslim dan negara-negara Barat. Ketiga, materi khotbah dan ceramah keagamaan tersirat intensitas gerakan pemurnian. Seiring dengan gerakan, berkhotbah keagamaan tersirat perlawanan terhadap budaya lokal (Jawa), yang dianggap sebagai sumber utama ketidakmurnian agama. Akhirnya, perkembangan Islam di Solo menyiratkan kecenderungan radikalisasi agama sebagaimana tercermin dalam sikap permusuhan terhadap budaya lokal, orang asing, dan nonMuslim. ${ }^{3}$

\footnotetext{
${ }^{1}$ Ridwan al-Makassari dan Ahmad Gaus (eds.), Benih-benih Islam Radikal di Masjid: Studi Kasus Jakarta dan Solo (Jakarta: Center for the Study or Religion and Culture (SSRC) UIN Syarif Hidayatullah Jakarta, 2010).

2 Ibid.

3 Zakiyuddin Baidhawy, "Muatan Nilai-nilai Multikultural dan Anti-Multikultural dari Mimbar Masjid di Kota Solo: Multiculturalism and Antimulticulturalism from Pulpits of Mosques", Jurnal Analisa, Vol. 21, No. 2 (Desember 2014), 173-187.
} 
Penulis mencoba mengamati beberapa media dakwah yang dipakai oleh kelompok radikal di masjid tidak hanya berkisar pada ceramah dan khutbah. Mereka gencar mensosialisasikan ideologinya melalui buku, majalah, portal online dan sebagainya. Sebagaimana artikel yang ditulis oleh Khamami Zada yang berjudul "Wajah Radikal Penerbitan Islam di Indonesia". Dalam risetnya ditemukan bahwa cukup banyak buku, majalah dan portal online Islam berasimilasi dengan organisasi keagamaan atau individu dengan paham keagamaan yang radikal. Munculnya ragam portal online dan penerbitan berbau radikal menjadi tren baru bagi gejolak pemahaman keagamaan radikal di Indonesia. Misalnya tabloid al-W $a^{\prime} i$ (tabloid yang dimiliki dan dikelola Hizbut Tahrir Indonesia), Pustaka At-Taqwa (dimiliki oleh Abu Salam, seorang Salafi), dan Jazeerah Solo (penerbit yang menerbitkan buku Imam Samudra berjudul Aku Melawan Teroris). Majalah, buku, dan portal online Islam ini tidak semata memiliki motivasi untuk kepentingan bisnis, tetapi bertujuan mendesiminasikan paham keagamaan tertentu. Bahkan, untuk penerbit-penerbit buku Islam menyelenggarakan Islamic Book Fair dalam beberapa tahun ini. Agenda ini memiliki maksud dan tujuan yang jelas untuk memasarkan bukubuku Islam radikal. ${ }^{4}$

Selain itu, ada beberapa pesantren yang tergugah memberikan kontra narasi ekstremisme dalam bentuk deradikalisasi kepada materimateri khutbah yang menjurus pada hate speech dan radikalisme. Pun dengan organisasi-organisasi lain yang tergugah melawan radikalisme yang berkembang dewasa ini, sebagaimana organisasi remaja masjid di beberapa tempat yang melakukan kontra radikalisme terhadap aktivitas-aktivitas remaja masjid di beberapa tempat di Jakarta. ${ }^{5}$ Ada potensi signifikan peran organisasi remaja masjid dalam mengupayakan deradikalisasi. Hasil penelitian mengindikasikan bahwa kedua organisasi tersebut dalam pengembangan wawasan keagamaan dan kebangsaan yang moderat. Selain itu ruang ekspresi budaya dan pembinaan kemandirian berupa kegiatan capacity building, pemberdayaan ekonomi dan apresiasi sosial, kesemuanya ini merupakan wujud dari kegiatan deradikalisasi.

\footnotetext{
${ }^{4}$ Khamami Zada, "Wajah Radikal Penerbitan Islam di Indonesia", Indo-Islamika, Vol. 1, No. 1 (2011), 1-19.

5 Muhammad Zulkifli, "Peran Organisasi Remaja Masjid DKI Jakarta dalam Deradikalisasi: Studi Kasus Remaja Islam Cut Meutia (RICMA) dan Remaja Islam Sunda Kelapa (RISKA)” (Tesis_-Universitas Indonesia, 2014).
} 
Artikel ini mengungkapkan dinamika pengarusutamaan moderasi Islam di Masjid Nasional Al-Akbar Surabaya dengan mencoba menganalisis bagaimana design moderasi Islam yang dikembangkan oleh para pengelola MAS dan juga melihat sejauh mana materi-materi khutbah yang disampaikan oleh para dai saat khutbah Jumat bisa mengarusutamakan Islam moderat.

\section{Kilas Sejarah Masjid Nasional Al-Akbar Surabaya}

Masjid Nasional Al-Akbar Surabaya atau yang biasa dikenal dengan Masjid Nasional al-Akbar Surabaya (MAS) ini didirikan pada 04 Agustus 1995, atas gagasan dari mantan Walikota Surabaya, Soenarto Soemoprawiro. Sedangkan peletakan batu pertama dilakukan oleh mantan Wakil Presiden, Try Sutrisno dan diresmikan mantan Presiden RI KH Abdurrahman Wahid pada tanggal 10 November 2000. Pemilihan 10 November sebagai hari peresmian karena hari itu sebagai hari jadi Kota Surabaya, sekaligus Hari Pahlawan. Selain itu, pemilihan waktu peresmian tersebut juga ditepatkan dengan hari jadi Institut Teknologi Sepuluh Nopember (ITS) Surabaya. Tim dari ITS yang merancang bangunan masjid tersebut. Sedangkan status sebagai masjid nasional diperoleh atas dasar Keputusan Menteri Agama Republik Indonesia Nomor 301 tahun 2003.

Semenjak peletakan batu pertama, proses pembangunan MAS ini mengalami perjalanan panjang untuk dapat mewujudkan keberadaan masjid dan tidak sedikit mengalami beberapa hambatan berat, utamanya ketika krisis ekonomi yang melanda Indonesia. Berkat tekad yang bulat, upaya yang tak henti-henti dan atas berkat dan rahmat serta berkah Allah, semua rintangan itu telah berhasil diatasi dengan baik. ${ }^{8}$

MAS ini diestimasikan untuk mewujudkan konsep masjid secara umum, yakni sebagai pusat keislaman dengan peran multidimensi dan misi religius, kultural dan edukatif, untuk mengimplementasikan Islam raḥmah li al-'álamin. Tanah untuk lokasi pendirian MAS disediakan oleh Pemerintah Daerah (Pemkot), dari tanah peruntukan fasilitas umum, ditambah lahan sawah penduduk yang telah dibebaskan. Luas areal komplek MAS adalah 11,2 Ha.

\footnotetext{
${ }^{8}$ Sambutan Try Sutrisno, Soekarwo, 16 Tahun Masjid Nasional Al-Akbar Surabaya 10 November 2000-2016) (Surabaya: Al Akbar, 2016), ii.
} 
Secara lahiriah, MAS menjadi landmark kota Surabaya dan secara simbolik eksistensi MAS memerkaya peta dunia Islam, yang tentunya diharapkan akan mengangkat citra kota Surabaya di mata dunia, baik regional, nasional dan internasional.

Dengan demikian MAS adalah wujud impian umat Islam Surabaya yang jumlahnya mendekati 5 juta, sekaligus menampung aspirasi 39 juta lebih warga Jawa Timur pada umumnya. Bangunan MAS didirikan di atas tanah seluas 11,2 hektar. MAS memiliki luas bangunan $28.509 \mathrm{~m} 2$ yang mampu menampung 36.000 jemaah dan berlokasi di kawasan Pagesangan Surabaya Selatan, atau lebih tepatnya di tepi jalan tol Surabaya-Malang.

Sebagai salah satu masjid terbesar di Indonesia, keberadaan MAS menjadi kebanggaan umat Islam Jawa Timur umumnya dan Surabaya khususnya, karena di Jawa Timur terdapat ribuan pondok pesantren dan MAS menjadi representasi dari kehidupan beragama umat Islam Jawa Timur. Menurut data BPS pada tahun 2013 jumlah penduduk di Jawa Timur mencapai kurang lebih 41,9 juta jiwa dan yang menganut agama Islam 94,6 persen. Jumlah masjid sebanyak 39.405 buah dan jumlah musala 106.290 buah. Untuk itu peran dan fungsi masjid sangat dibutuhkan kehadirannya untuk membangun dasar kehidupan umat. Sebagai tempat ibadah masjid merupakan media seorang hamba berkomunikasi dengan Penciptanya dalam bentuk salat. Di samping sebagai sentral kegiatan tentunya masjid memiliki multifungsi; fungsi keagamaan, pendidikan, ekonomi, sosial, kesehatan dan sebagainya.

MAS semenjak diresmikan, secara kontinyu, utamanya sejak tahun 2007 telah melakukan upaya peningkatan pelayanan dengan melakukan berbagai inovasi, khususnya di bidang pengelolaan dan pelayanan kepada umat. Penataan manajemen dimulai dengan penyusunan Rencana Strategis (renstra) dan program kerja, penataan organisasi, pelayanan peribadatan, peningkatan kebersihan masjid secara keseluruhan, baik di ruang ibadah, tempat wudu (toilet dan kamar mandi) maupun halaman dan lingkungan masjid ${ }^{9}$ serta keasrian taman yang dilengkapi dengan gasebo untuk sekadar bersantai sambil bermedia sosial.

Sebagaimana fungsi masjid pada umumnya, MAS selain fungsi utama sebagai tempat ibadah salat dan kegiatan keagamaan lainnya, juga difungsikan untuk kegiatan pendidikan, sosial budaya dan

\footnotetext{
${ }^{9}$ Sambutan Direktur Utama Drs. H. Endro Siswantoro pada hari ulang tahun ke 16 Masjid Nasional Al-Akbar Surabaya, 16 Tahun Masjïd Nasional Al-Akbar Surabaya, i.
} 
ekonomi guna mewujudkan masyarakat yang berakhlak mulia sesuai dengan tuntunan agama Islam.

Dilihat dari aspek tata kelola (manajemen), struktur, personalia, dan program kerja MAS ini nampak modern, lengkap dan tersistem yang diharapkan dapat memenuhi kebutuhan umat. Karena modernnya pengelolaan atau manajemen masjid ini wajar jika kemudian menjadi masjid percontohan yang sering dijadikan objek studi banding masjid-masjid lainnya serta menjadi destinasi wisata Surabaya atau Jawa Timur yang sering dimasukkan dalam paket ziarah Walisongo oleh para agen pelaksana ziarah. Masjid ini telah beberapa kali memperoleh penghargaan seperti sebagai masjid favorit, ${ }^{10}$ masjid dengan toilet terbersih, ${ }^{11}$ sebagai salah satu destinasi wisata religi ${ }^{12}$ dan lain-lain. ${ }^{13}$

MAS ini berbentuk Badan Pengelola (sejak berdiri hingga Februari 2019), yang diatur dan ditata oleh Pemerintah Propinsi Jawa Timur, dan bukan dalam bentuk yayasan. Sedangkan susunan Badan Pengelola MAS periode 2011-2015 berdasarkan Surat Keputusan Gubernur Jawa Timur Nomor 188/59/KPTS/013/ 2011, tertanggal 18 Februari 2011 terdiri dari Imam Besar, Direktur Utama, Wakil Direktur Utama, Direktur Idaroh, Direktur Imaroh/Ijtimaiyah, Direktur Shiyanah, Direktur/Mudir Ma‘had Aly/Sekolah Tinggi Ilmu Ushuluddin/Sekolah Tinggi Agama Islam al-Akbar.

Sedangkan Pengelola MAS periode 2016-2018 sesuai Surat Keputusan Gubernur Propinsi Jawa Timur Nomor 188/288/KPTS /013/2016, tertanggal 1 Juli 2016 terdiri dari Dewan Pendiri, Dewan Pembina, Imam Besar, Dewan Direksi (Direktur Utama, Direktur Idarah, Direktur Imarah, dan Direktur Tarbiyah).

Selanjutnya masing-masing Direktur mempunyai bagian-bagian yang secara teknis melaksanakan tugas-tugas harian, seperti Bidang Administrasi Umum, Bidang Keuangan, Bidang Humas, Bidang Usaha, Bidang Infaq, Bidang Sosial, Bidang Keamanan, Bidang

\footnotetext{
10 Surabaya Tourism 1s Destination Award tahun 2012 yang diselenggarakan oleh Dinas Kebudayaan dan Pariwisata Kota Surabaya bekerja sama dengan Universitas Ciputra dan Suara Surabaya Media.

11 Juara 1 Lomba Toilet Publik 2004 Kategori Objek Wisata, diselenggarakan oleh Walikota Surabaya pada Hari Jadi Kota Surabaya ke 711 Tahun 2004.

12 Pemenang Informasi Komunikatif 2012 dan pada Lomba Objek Touris Kategori Comunicatie Information Surabaya Tourism 2 $2^{\text {st }}$ Destination Award tahun 2013.

${ }^{13}$ Helmi M. Noer (Kepala Bidang Hubungan Masyarakat Masjid Nasional al-Akbar Surabaya), Wawancara, Surabaya 3 Desember 2017.
} 
Perawatan, Bidang Dakwah, Bidang Pengajian Wanita, Bidang Perlengkapan, Bidang Pendidikan (Kelompok Bermain KB-RA, Madrasah Ibtidaiyah, Ma'had Aly), Bidang Pelatihan dan Kajian, dan Bidang Perpustakaan.

Semenjak diresmikan, struktur organisasi pengelolanya mengalami beberapa perubahan, yakni periode pertama 2000-2006, periode kedua 2007-2010, periode ketiga 2011-2015, dan periode keempat 20162018. Masjid ini berbeda dengan masjid-masjid lain pada umumnya dalam menggunakan nomenklatur jabatan pengelolanya, baik pada masjid negara, masjid nasional, masjid besar, masjid jami', masjid khusus dan sebagainya. Hanya MAS yang pertama kali menggunakan nama jabatan kepengelolaannya/ketakmirannya dengan nomenklatur "Direktur Utama dan para Dewan Direksi". Sementara masjid-masjid lain pada umumnya menggunakan nama pengelola/ketakmirannya dengan istilah ketua takmir dan sebagainya. Biasanya istilah direktur itu dipakai pada jabatan di perusahaan-perusahaan besar seperti Badan Usaha Milik Negara (BUMN). Nomenklatur ini digunakan terdapat pesan moral yang besar sebagai amanat suci harus diemban oleh para direktur dan dewan direksi (pengurusnya). Artinya, kapabilitas, profesionalitas, dan tanggung jawab menjadi persyaratan utama dalam melaksanakan amanah suci ini, yang harus dipertanggungjawabkan tidak hanya kepada umat, tetapi sekaligus kepada Allah. ${ }^{14}$

Dalam pelayanan kepada jemaah, MAS menggunakan layanan mutu berbasis ISO 9001:2008 semenjak tahun 2009. Masjid pertama yang berhasil meraih sertifikat ISO adalah Masjid al-Ikhlas Jatipadang Pasar Minggu Jakarta Selatan. ${ }^{15}$ Sedangkan MAS adalah peraih sertifikat ini yang kedua. ISO ini mengamanati lima hal yang urgen, yakni: 1) Memenuhi kebutuhan jemaah dan pihak-pihak berkepentingan di bidang pelayanan peribadatan, dakwah, sosial dan pendidikan serta peraturan perundangan yang berlaku, 2) Mengelola sarana dan prasarana peribadatan serta sarana pendudung lainnya sesuai kebutuhan pelayanan jemaah dan perkembangan teknologi, 3) Meningkatkan kompetensi dan profesionalisme Sumber Daya Manusia (SDM) di bidang manajemen Masjid Nasional Al-Akbar, 4) Meningkatkan kinerja dan efektivitas penerapan sistem Manajemen Mutu secara berkesinambungan berbasis manajemen risiko, dan 5)

\footnotetext{
14 Ibid.

15 Agus Mubarok, Problematika Masjid dan Solusinya (Bandung: Emqies Publishing, 2017), 183.
} 
Menjalin kerjasama dan kemitraan dengan lembaga dakwah baik skala Nasional maupun internasional. ${ }^{16}$

Sementara untuk kebijakan kebersihan dan Lingkungan MAS mengetrapkan Program 5R. Pokok-pokok Pedoman Pelaksanaan 5R adalah: 1) Ringkas: Menata yang diperlukan dan menyingkirkan yang tidak diperlukan, 2) Rapi: Susun secara sistematis sesuai dengan fungsinya agar mudah mencari atau mengembalikan, 3) Resik: Bersihkan tempat kerja dan peralatan sehingga teratur dan indah, 4) Rawat: Pertahankan hasil yang dicapai dengan membuat standar, prosedur dan mekanisme, dan 5) Disiplinkan diri sesuai norma-norma dan nilai-nilai yang disepakati. ${ }^{17}$

Seluruh pemangku jabatan dan para khädim/karyawan MAS harus bekerja dan berkinerja maksimal serta profesional atas tugas pokok dan fungsi kewajibannya (tupoksi) sebagai amanah besar, suci dan mulia ini. Oleh sebab tugas besar dan suci ini dimunculkanlah motto "Ikhlas Profesional"18 bagi pengurus dan karyawan MAS ini. Karena "Ikhlas Profesional" ini, maka semua pemangku jabatan dan karyawannya diberi imbalan ('ujrah atau bisharah) sepantasnya sebagaimana gaji pegawai/karyawan pada umumnya berdasarkan kemampuan keuangan Masjid.

Untuk kebutuhan operasional, MAS diperoleh dari berbagai sumber dana yang halal dan tidak mengikat seperti donatur, bantuan Pemerintah Propinsi (Pemprov) dalam bentuk kegiatan Peringatan Hari-hari Besar Islam (PHBI), Infaq Jumat, Infaq Harian, Infaq Akad Nikah, Infaq Parkir, Wisata Menara, Sewa Gedung Resepsi, biaya pendidikan dan lain-lain yang diketuai oleh bagian Badan Usaha Masjid. $^{19}$

Dengan demikian, mereka yang dapat amanat untuk mengurus atau khädim dalam melaksanakan tugas-tugas di masjid ini dapat dikatakan "beribadah dan bekerja atau bekerja dan beribadah". Atas motivasi dan niat seperti ini, maka para khädim Masjid merasa lebih eksis dan survive sebagai pekerja MAS ini, karena bagi mereka yang benar niatnya pasti akan memperoleh janji pahala akhirat dan dunia

\footnotetext{
${ }^{16}$ Dokumen Masjid Al-Akbar.

17 Ibid.

18 Istilah "Ikhlas Profesional" ini adalah gagasan yang dimunculkan oleh Prof. Dr. H. Ahmad Zahro, MA sebagai pemangku jabatan Kepala Bidang Ibadah periode 2008-2012.

19 Hendro (Direktur Utama Masjid Nasional al-Akbar Surabaya), Wawancara, Surabaya 01 Desember 2017.
} 
sekaligus. Mereka bisa survive dan merasa lebih nyaman bekerja di masjid daripada bekerja di tempat lainnya, sebab irama kerja mereka tidak akan mengganggu ibadahnya. Artinya, jadwal tugasnya tidak berbenturan dengan jadwal waktu ibadah (salat), sehingga diharapkan di samping imbalan dunia, juga mendapat pahala akhirat (fí al-dunyā ajr wa fi al-äkbirah ujür). ${ }^{20}$ Oleh sebab itulah, maka seluruh khädim (karyawan) MAS senantiasa siap dan ikhlas mengabdi serta pihak manajemen terus memperhatikan, membina dan meningkatkan skill dan profesionalitasnya melalui pelatihan-pelatihan kerja, agar kinerja mereka maksimal sesuai standar yang diharapkan. Jadi, persoalan Sumber Daya Manusia (SDM) karyawan MAS sangat diperhatikan, termasuk dibina dan ditingkatkan pengetahuan agamanya. ${ }^{21}$ Semua kekuatan yang ada sebagai upaya untuk bisa berkhidmat kepada agama dan umat.

Jika mengacu pada profil masjid ideal, maka MAS telah memenuhi syarat sebagai masjid ideal. Masjid ideal memiliki kriteria, di antaranya: 1) bidang kepengurusan, 2) bidang kejemaahan, 3) Bidang program, 4) bidang peribadatan, 5) Bidang pendidikan dan dakwah, 6) Bidang sosial, 7) Bidang penerangan, dokumentasi dan publikasi, 8) Bidang dana, 9) Bidang kesekretariatan, 10) bidang remaja, 11) bidang kewanitaan, 12) bidang fisik bangunan masjid, 13) bidang inventaris masjid, 14) bidang hubungan dengan masjid lain. ${ }^{22}$ Bahkan MAS telah melampaui kriteria tersebut. Hal itu bisa dibuktikan di lapangan (terdapat beberapa fasilitas lainnya seperti pemancar radio, lembaga pendidikan formal di samping non formal dan informal, koperasi dan sebagainya). Dengan demikian dapat dikatakan bahwa MAS dari sisi pengelolaannya dan fasilitas sarana dan prasarana pendukungnya pantas dibanggakan.

Berkaitan dengan hal tersebut MAS telah memiliki ragam fasilitas serta sarana dan prasarana yang memadai, sehingga dari masjid ini

\footnotetext{
${ }^{20}$ Ungkapan "fī al-dunyā ajr wa fì al-ākhirah ujūr" adalah slogan yang diberikan oleh Ahmad Zahro mengomentari kemampuan masjid didalam menghargai kualifikasi para imam yang akan bertugas mengemban amanat suci ini. Tentu hal itu juga berlaku pada seluruh atau siapapun yang bertugas di Masjid Nasional al-Akbar Surabaya. Suatu ungkapan rendah hati yang luar biasa dari seorang penanggungjawab bidang ibadah di dalam memelihara murüab keimaman dan alakhlāq al-karimah yang harus menjadi karakter dasar pengabdi masjid.

21 Endro Siswantoro (Direktur Utama Masjid Nasional al-Akbar Surabaya), Wawancara, 2 Desember 2017.

${ }^{22}$ Ahmad Yani, Mencintai Masjid (Jakarta: Pustaka Harum, 2002), 11-20.
} 
Islam perlu meneguhkan kembali identitas terbaiknya sebagai pusat pembinaan agama sekaligus membangun peradaban yang menjadi solusi bagi kompleksitas permasalahan hidup dan kehidupan manusia.

Masjid Nasional al-Akbar Surabaya terus melakukan perbaikan dalam berbagai aspek, baik di bidang pelayanan maupun pembenahan sarana dan prasarana sesuai kebutuhan umat. Perbaikan (improvement) diperlukan untuk meningkatkan kinerja untuk memberikan pelayanan prima kepada jemaah. Beberapa cara yang cukup efektif dalam upaya perbaikan dapat diseleksi dan disesuaikan dengan kebutuhan, agar upaya perbaikan dapat dilaksanakan secara berkelanjutan. ${ }^{23}$

\section{Konstruksi Moderasi Islam di Masjid Nasional Al-Akbar Surabaya}

Pengarusutamaan Moderasi Islam di Masjid Nasional al-Akbar Surabaya (MAS) sesungguhnya sesungguhnya telah tergambar sejak semula dari keinginan para dewan pendirinya. Hal ini tersurat dari piagam MAS sebagaimana dipampang di pintu masuk utama sisi kiri MAS, ditulis di atas batu granito bermotif marmer, dibuat tahun 2000 . Isi piagam tersebut adalah:

1. Masjid Al-Akbar dibangun semata-mata untuk mencari keridaan Allah dan merupakan amanat umat yang dipertanggungjawabkan kepada Allah.

2. Masjid Al-Akbar dibangun bersama oleh masyarakat dan pemerintah melalui amanat yang dipercayakan kepada Dewan Pendiri Masjid Nasional al-Akbar Surabaya.

3. Masjid Nasional al-Akbar Surabaya dibangun untuk kemaslahatan umat dan syiar Islam.

4. Masjid Nasional al-Akbar Surabaya dalam melaksanakan ibadah dalam arti seluas-luasnya senantiasa berpegang kepada al-Qur'ān dan Hadis.

5. Masjid Nasional al-Akbar Surabaya khusus dalam penyelenggaraan kegiatan ibadah salat berkiblat kepada penyelenggaraan di Masjidil Haram Mekkah". ${ }^{24}$

Pada piagam itu tercermin arah dan tujuan dibangunnya masjid ini untuk semata-mata mencari rida Allah dengan berpegang teguh

23 Sambutan Gubernur Jawa Timur, Soekarwo, 16 Tabun Masjid Nasional Al Akbar Surabaya (10 November 2000-2016) (Surabaya: Al Akbar, 2016), iii.

${ }^{24}$ Dokumen Prasasti ini tercantum nama-nama dewan pendiri, yaitu Try Sutrisno, Imam Utomo, Basofi Sudirman, Tarmidzi Taher, Mar'ie Muhammad, Husein Supranoto, dan Walikota Surabaya ex oficcio. 
kepada al-Qur'ān dan Hadis dan kemaslahatan umat serta berkiblat kepada Masjidil Haram dalam persoalan ibadah dalam arti seluasluasnya. Masjid ini diharapkan dapat memberikan pelayanan kepada umat dalam arti seluas-luasnya dapat dilihat dari visi, misi, motto, dan nilai yang telah ditetapkan.

Adapun visi MAS adalah "Masjid nasional terdepan dalam penyelenggaraan dakwah dan syiar Islam, pendidikan, sosial budaya dan manajemen menuju masyarakat yang berakhlak mulia sesuai ajaran Islam". Sedangkan misinya adalah: 1) penyelenggaraan ibadah dakwah dan syiar Islam, 2) Pengembangan Pendidikan Islam, 3) Pengembangan sosial budaya Islam, 4) Mewujudkan manajemen masjid yang handal, dan 5) Mewujudkan masyarakat berakhlak mulia.

Selain itu MAS bermotto "Ikhlas Profesional", yang memiliki nilai-nilai: amānah, istiqāmah, uswah, mas'ülīyah dan li jamī' al-ummah. ${ }^{25}$ Dalam arti tugas-tugas suci yang dipikulkan kepada pengelola MAS harus dijaga secara terus-menerus dan senantiasa menjadi contoh dan dipertanggungjawabkan baik kepada Allah maupun kepada jemaah.

Konstruksi Islam Moderat Masjid Nasional al-Akbar Surabaya sebagaimana dikawal oleh pengurusnya dilakukan mulai dari ketika memilih dai, khatib, imam, menentukan materi-materi kajian, dan kitab-kitab yang dijadikan rujukan. Penentuan dai/khatib sangat penting, sebab jika salah pilih khatib/dai dan materi dakwah bisa menimbulkan keresahan di masyarakat.

Dalam menjaring para dai MAS, demikian Roem Rowi menyatakan: "Sesungguhnya tidak ada seleksi khusus untuk kriteria dai. Untuk kriteria umum untuk menentukan khatib/dai yang dilakukan selama ini adalah dengan memperhatikan bidang kualifikasi keilmuan mereka berdasarkan kedudukan dan atau popularitasnya di bidang dakwah dan kajian keislaman yang telah jamak diketahui masyarakat. Namun demikian pengurus terus memantau dan mengevaluasi performa dan karakter dakwah mereka. ${ }^{26}$

Terdapat beberapa aspek yang menjadi perhatian pengelola di dalam menjaga visi dan misi MAS dalam dakwah menebarkan Islam rahmah li al-älamin, yaitu: pertama, tidak fanatik golongan. Jika materi yang disampaikan oleh khatib/dai senantiasa hanya menjunjung tinggi

\footnotetext{
25 Visi, Misi, Motto dan Nilai Manajemen Masjid Nasional al-Akbar ini diabadikan pada pigora yang dipampang pada ruangan masjid Nasional al-Akbar Surabaya.

26 Roem Rowi (Imam Besar/Mantan Direktur Imarah Masjid Nasional al-Akbar Surabaya), Wawancara, Surabaya 03 Maret 2017.
} 
golongan dan alirannya, maka termasuk yang harus dievaluasi dan dilakukan tindakan lebih lanjut. Kedua, tidak membincangkan dan atau mengarahkan secara terbuka kepada politik praktis. Isi ceramah tidak boleh menggiring jemaah untuk kepentingan politik praktis, sebab akan memicu sentimen pendukung partai tertentu. Ketiga, tidak mempersoalkan masalah-masalah khiläfyyah yang telah hidup dan diamalkan oleh para ulama yang mengarah kepada fanatisme golongan aliran agama tertentu. Masalah khiläfizah yang memiliki dasar metolologis fiqhi sangat terbuka terjadinya perbedaan pendapat. Untuk itu sejak dari awal, garis besar dan arah kebijakan di bidang ibadah telah ditentukan oleh MAS, yaitu senantiasa berkiblat ke Masjidil Haram. Hal ini dilakukan dalam rangka mengantisipasi adanya fanatisme golongan yang bisa memicu masalah khiläfỹyah di bidang ibadah yang sering menjadi konflik antar-aliran keagamaan. ${ }^{27}$

Untuk keperluan di atas MAS membuat Standar Operational Procedure (SOP) bidang Dakwah dan Kajian Keislaman, dengan garisgaris besar kebijakan sebagai berikut.

1. Kajian keislaman terjadwal sesuai tema dan subtema kajian.

2. Penceramah dan narasumber yang telah ditentukan dengan dengan kualifikasi keagamaan di atas rata-rata jemaah.

3. Dihindari penyampaian yang bersifat kbiläfiyah kecuali untuk kajian pencerahan.

4. Dihindari penyampaian ceramah atau kajian keislaman yang bersifat dukung-mendukung pasangan calon tertentu.

5. Tidak diperkenankan berpolitik atau kampanye di masjid, kecuali pendidikan politik.

6. Penceramah harus bebas dari paham liberalisme, radikalisme, wahabisme, paham-paham atau aliran keagamaan yang menyimpang, anti-NKRI dan Pancasila.

Sedangkan untuk Peringatan Hari-hari Besar Islam adalah:

1. Peringatan Hari Besar Islam, dilaksanakan sesuai dengan eveneven yang disepakati (Tahun Baru Islam (Muharram), Maulid Nabi Muhammad saw, Isra` Mi’raj, Nisfu Sya’ban, Nuzulul Quran, dan Halal Bihalal).

2. Penceramah yang ditunjuk adalah mereka yang berkompeten dengan skala nasional atau internasional.

3. Dakwah yang disampaikan santun dan menyejukkan.

${ }^{27}$ Ibid. 
4. Dihindari penceramah yang menjurus pada Hoax, ujaran kebencian (hate speech), fitnah dan provokatif.

5. Menampilkan seni dan budaya Islam; Hadrah, Sholawat al-Banjari, dan kesenian Islami, Tari Javin dan sebagainya dengan tempat menyesuaikan. ${ }^{28}$

Dengan SOP di atas, maka kualifikasi khatib/dai dan karakter dakwahnya haruslah tidak keluar dari pedoman SOP MAS. Artinya performa khatib/dai adalah senantiasa berorientasi kepada Islam raḥmah li al-älamin, yang mengedapankan al-akbläq al-karimah, yang santun, menyejukkan, tidak menyebar kebencian, bukan provokatif dan hoax, tidak berkampanye untuk kepentingan politik praktis dan tidak membesar-besarkan khiläfiyah yang menjurus kepada perpecahan, tidak mengajarkan dan menyebarkan paham liberalisme, fundamentalisme, radikalisme, aliran sesat, anti-Pancasila dan NKRI. ${ }^{29}$

Dari sini nampak konstruksi dakwah Islam Moderat yang dikawal oleh MAS, yakni Islam yang memberi rahmat dengan performa dakwah/ceramah yang mengedepankan al-akbläq al-karimah dan bersifat tawāsut, tawāzun, ta'ädul, tasämuh, bertutur santun, sejuk, menghargai, menghormati demi menjunjung tinggi ukhuwwah (islämiyah, wataniyah, dan bashariyah) dan tidak anti-Pancasila dan NKRI.

Selanjutnya strategi yang dilakukan MAS ketika memilih imam. MAS memiliki beberapa imam, baik imam besar maupun imam rawatib. Imam besar diangkat melalui Surat Keputusan yang dikeluarkan oleh Pemerintah Provinsi Jawa Timur. Imam besar yang diangkat oleh Pemprov tersebut melibatkan organisasi sosial keagamaan seperti Nahdhatul Ulama (NU), Muhammadiyah dan AlIrsyad. Namun yang eksis saat ini adalah dari NU dan Muhammadiyah. Sedangkan imam rawatib diangkat oleh Direktur MAS sendiri. Saat ini imam rawatib MAS sebanyak tujuh orang. Mereka berasal dari dua organisasi, NU dan Muhammadiyah. ${ }^{30}$ Artinya, MAS memiliki kriteria untuk jabatan imam. Hal ini sebagaimana dituturkan Sumarkan dan Roem Rowi.

\footnotetext{
${ }^{28}$ Dokumen bidang Dakwah dan Kajian Masjid Nasional Al-Akbar, Surabaya, 10 Februari 2017.

29 Sumarkan (Direktur Ibadah Masjid Nasional al-Akbar Surabaya), Wawancara, Surabaya 04 Maret 2017.

${ }^{30}$ Roem Rowi (Imam Besar/Mantan Direktur Imarah Masjid Nasional al-Akbar Surabaya), Wawancara, Surabaya 03 Maret 2017.
} 
"Sebenarnya MAS tidak memerhatikan komposisi latar organisasi keagamaan khatib/dai, tetapi cukup dengan melihat reputasi, kualifikasi keilmuannya. Khatib/dai yang ada selama ini adalah dari kalangan kampus, kiai pondok pesantren dan sebagainya. Jika ternyata dari kalangan khatib/dai Nahdhiyyin lebih dominan itu bisa dianggap wajar, karena Jawa Timur sebagai basis pesantren mayoritas jemaahnya adalah Nahdhiyyin. Demikian pula kualifikasi para imam besar dan rawatib telah merepresentasikan dari kedua organisasi itu (NU dan Muhammadiyah). ${ }^{\text {31 }}$

Sedangkan Roem Rowi menegaskan.

"Tidak penting dari kelompok mana, tetapi yang diperhatikan adalah performa, corak dakwah yang sifatnya merangkul, menghargai, dan mengedepankan akhlaq, sehingga Islam yang merahmati dapat terwujud di MAS bagi semuanya, tetapi tidak dipungkiri bila afiliasi mereka dari kelompok Islam mainstream (NU dan Muhammadiyah)."32

Menurut SK Dirjen Bimas Kementerian Agama RI No. 582 tahun 2017, ada delapan syarat untuk menjadi Imam masjid. Syarat tersebut antara lain: Islam, laki-laki, dewasa, adil, sehat jasmani dan rohani, berakhlak mulia, berpaham Ahl al-Sunnah wa al-Jamā'ah, dan memiliki komitmen terhadap dakwah Islam.

Adapun kompetensi umum imam masjid tetap, antara lain: memiliki pemahaman terhadap fiqh salat, memiliki kemampuan membaca al-Qur'ān dengan taḥsin dan tartïl, memiliki kemampuan untuk membimbing umat, memahami problematika umat, memiliki kemampuan memimpin salat, zikir dan doa rawātib, memiliki kemampuan berkhotbah, dan memiliki wawasan kebangsaan.

Sedangkan kompetensi khusus imam masjid, terdapat ketentuan khusus yang dimiliki oleh imam tetap masjid. Kompetensi khusus ini dibagi menjadi tujuh bagian berdasarkan tipologi masjid. Adapun pembagian kompetensi khusus adalah sebagai berikut:

1. Kompetensi Imam tetap Masjid Negara

A. Pendidikan minimal Strata Satu.

B. Memiliki hafalan al-Qur'ān 30 juz.

C. Memiliki keahlian membaca al Qur'ān dengan suara merdu.

D. Memiliki pemahaman tentang fiqih, hadis dan tafsir.

31 Sumarkan (Direktur Ibadah Masjid Nasional al-Akbar Surabaya), Wawancara, Surabaya 7 Desember 2017.

32 Roem Rowi (Imam Besar/Mantan Direktur Imarah Masjid Nasional al-Akbar Surabaya), Wawancara, Surabaya 12 Maret 2017. 
E. Mampu berkomunikasi dengan Bahasa Arab dan salah satu Bahasa Asing lainnya.

2. Kompetensi Imam Tetap Masjid Nasional dan Masjid Raya

A. Pendidikan minimal S-1 atau yang sederajat.

B. Memiliki hafalan al-Qur'ān 10 juz.

C. Memiliki keahlian membaca al Qur'ān dengan suara merdu

D. Memiliki pemahaman tentang fiqih, hadis dan tafsir.

E. Mampu berkomunikasi dengan Bahasa Arab dan salah satu Bahasa Asing lainnya.

3. Kompetensi Imam Tetap Masjid Masjid Agung Tingkat Kabupaten

A. Pendidikan minimal S-1 atau yang sederajat.

B. Memiliki hafalan al-Qur'ān 2 juz.

C. Memiliki keahlian membaca al Qur'ān dengan suara merdu.

D. Memiliki pemahaman tentang fiqih, hadis dan tafsir.

4. Kompetensi Imam Tetap Masjid Besar Tingkat Kecamatan

A. Pendidikan minimal S-1 atau yang sederajat.

B. Memiliki hafalan al-Qur'ān minimal juz 30.

C. Memiliki keahlian membaca al Qur'ān dengan suara merdu.

D. Memiliki pemahaman tentang fiqih, hadis dan tafsir.

5. Kompetensi Imam Tetap Masjid Jami'

A. Pendidikan minimal Pondok Pesantren/SLTA/yang sederajat.

B. Memiliki hafalan al-Qur'ān minimal juz 30.

C. Memiliki keahlian membaca al Qur'ān dengan suara merdu.

D. Memiliki pemahaman tentang fiqih, hadis dan tafsir.

6. Kompetensi Imam Tetap Masjid Bersejarah

A. Pendidikan minimal Pondok Pesantren/SLTA/yang sederajat.

B. Memiliki hafalan al-Qur'ān minimal juz 30.

C. Memiliki keahlian membaca al-Qur'ān dengan suara merdu.

D. Memiliki pemahaman tentang fiqih, hadis dan tafsir.

E. Memahami sejarah berdirinya masjid.

7. Kompetensi Imam Tetap Masjid di Tempat Publik

A. Pendidikan diutamakan Pondok Pesantren/SLTA/yang sederajat.

B. Memiliki hafalan al-Qur'ān minimal juz 30.

C. Memiliki keahlian membaca al Qur'ān dengan suara merdu.

D. Memiliki pemahaman tentang fiqih, hadis dan tafsir.

Imam besar sesungguhnya adalah jabatan kehormatan yang diberikan oleh Pemprov dan MAS. Imam besar adalah tokoh dan 
pakar yang diangkat dari organisasi keagamaan (seperti NU dan Muhammadiyah). Mereka menjadi representasi dari kelompok Islam maintream. Sedangkan imam rawatib diangkat oleh MAS. Imam rawatib MAS yang ada saat ini terdiri dari para hafiz, qari dan akademisi. Beberapa kriteria telah terpenuhi oleh mereka seperti kompetensi umum, kompetensi khusus dan kompetensi kualifikasinya.

Sedangkan materi kajian rutin yang diselenggarakan oleh MAS setiap hari di waktu Maghrib-Isya' dan Subuh cukup variatif, mulai dari al-Qur'ān dan Tajwid, Tafsir Taḅlizl, Tafsir Mawdūù, Hadis, Tafsir Kependidikan, Aqidah Tauhid/Teologi Islam/Ilmu Kalam, Tasawuf, Fadilah al-Qur'ān, Mutiara Tausiah Rasul, Aplikasi Akhlak Rasulullah, Akhlak Tasawuf, Fiqih Muamalah, Kesehatan, Titian Menggapai Hidayah, Sejarah Fuqaha' Sepanjang Masa, Hadis Aqidah Akhlak, Islam dan Budaya, Sirah Nabawiah, Fiqih, Ekonomi Bisnis, Manageman, Fatwa MUI, Sejarah Peradaban Islam, dan sebagainya. Demikian pula kitab acuan yang dikaji oleh para dai, seperti kitab Riyàd al-Sălibin, Ibyà' 'Ulüm al-Dìn, Ta'lim al-Muta'allim, al-Hikam, Bulügh al-Marām, dan sebagainya.

Seluruh kajian yang diselenggarakan di MAS bersifat terbuka untuk umum, tidak eksklusif, dan setiap kajian senantiasa disediakan waktu tanya jawab secukupnya, sehingga segala sesuatu dapat didialogkan dengan para jemaah melalui forum dialog tersebut. ${ }^{33}$

Demikian pula dengan materi khotbah Jumat di MAS telah ditentukan tema-temanya. Materi khotbah meliputi aqidah, ibadah, akhlak, sosial keagamaan dan sebagainya. Dengan adanya tema-tema tersebut para dai menyampaikan materi khotbahnya sesuai garis kebijakan Masjid. Dakwah yang dikawal oleh MAS seperti dimaklumi adalah Islam Moderat, Islam rạ̣mah li al-älamin, tawāsut, tawā̃un, ta'ädul, dan tasämuḅ dalam bingkai amr ma'rǘf bi al-ma'rüf wa naby 'an almunkar bi al-ma'ruf.

Mantan Direktur Imarah Ijtimaiyah Masjid Nasional Al-Akbar Surabaya Muhammad Roziqi menuturkan.

"Islam rạmah li al-älamin adalah Islam yang menebarkan dan menyebarkan dakwahnya dengan kasih sayang, ramah, santun, sejuk, senantiasa berdakwah dengan hikmah, maw 'ža ha hasanah dan jika perlu

33 Kholiq Idris (Kepala Bidang Ibadah Masjid Nasional al-Akbar Surabaya), Wawancara, Surabaya 5 Februari 2017. Kajian rutin harian ini sudah berjalan sejak diresmikan, yakni tahun 2000 . 
berdialog dengan cara-cara yang terbaik, sebagaimana difirmankan Allah dalam surah al-Nahl [16], 125". Dakwah sesungguhnya melakukan amr ma'rüf wa naby 'an al-munkar harus dilakukan dengan cara-cara yang ma'rüf. Jadi, ber-amr ma'rüf bi al-ma'rüf wa naby 'an almunkar bi al-ma'rūf..$^{34}$

Berikut potret materi khotbah Jumat di MAS yang mencerminkan adanya pengarusutamaan Islam Moderat.

Tabel 2.1

Materi Khotbah Para Dai Masjid Nasional al-Akbar Surabaya

\begin{tabular}{|c|c|c|}
\hline No & $\begin{array}{l}\text { Dai/Tema } \\
\text { Khotbah/ Tahun }\end{array}$ & Kesimpulan Khotbah \\
\hline 1 & $\begin{array}{l}\text { Sofwan/Merajut } \\
\text { Ukhuwah } \\
\text { Islamiyah/2016 }\end{array}$ & $\begin{array}{l}\text { Islam memiliki kekuatan yang luar biasa, } \\
\text { bahkan sudah diakui oleh umat lain, seperti } \\
\text { Belanda yang mengakui kehebatan umat } \\
\text { Islam Indonesia, yang tidak takut bom atau } \\
\text { senjata apapun sehingga mampu } \\
\text { menggempur musuh kala itu. Umat Islam } \\
\text { harus sadar dan segera merajut kembali } \\
\text { persaudaan di antara umat Islam. Tidak usah } \\
\text { mempertajam perbedaan yang furúcyah, } \\
\text { karena bukan hal yang prinsip. Yang } \\
\text { dikedepankan adalah menghormati pendapat } \\
\text { orang lain, dan tidak memaksakan pendapat } \\
\text { kita sendiri. Untuk membangun kembali } \\
\text { ukhumwah islämiyah harus ditanamkan rasa } \\
\text { solidaritas. Wujud dari solidaritas islami } \\
\text { adalah beramar makruf nahi munkar, } \\
\text { berdakwah ilä Allăh, dan memberi petunjuk } \\
\text { manusia pada sebab-sebab kebahagiaan di } \\
\text { dunia dan akhirat. Termasuk di dalamnya } \\
\text { juga, mengajari orang-orang yang jahil atas } \\
\text { urusan agama mereka, menolong orang- } \\
\text { orang yang dizalimi, dan mencegah orang- } \\
\text { orang vang zalim atas yang lainnya. }\end{array}$ \\
\hline 2 & $\begin{array}{l}\text { Burhan } \\
\text { Djamaluddin/Jihad } \\
\text { Akbar bukan }\end{array}$ & $\begin{array}{l}\text { Jihad adalah menggunakan segala kekuatan, } \\
\text { kemampuan dan daya upaya untuk } \\
\text { melakukan }\end{array}$ \\
\hline
\end{tabular}

\footnotetext{
${ }^{34}$ Muhammad Roziqi (Direktur Imarah Ijtimaiyah Masjid Nasional Al-Akbar 20122016, Ketua PWDMI Jawa Timur Periode 2013-2017), Wawancara, Surabaya, 14 Desember 2017.
} 


\begin{tabular}{|c|c|c|}
\hline & $\begin{array}{l}\text { Sembarang } \\
\text { Jihad/2016 }\end{array}$ & $\begin{array}{l}\text { menyampaikan kebenaran di hadapan } \\
\text { penguasa yang zalim. Maka kalau ada orang } \\
\text { yang mampu menyampaikan teguran dan } \\
\text { kritikan, maka itu termasuk kategori jihad. } \\
\text { Musuh-musuh Islam mempropagandakan } \\
\text { bahwa Islam tersebar luas di seluruh penjuru } \\
\text { dunia disebabkan dakwah kaum Muslimin } \\
\text { dengan pedang dan perang. Padahal } \\
\text { kenyataannya tidak demikian. Dalam surah } \\
\text { al-Furqān ayat } 52 \text { menerangkan bahwa jihad } \\
\text { pemikiran, intelektual dan budaya harus } \\
\text { didahulukan dari segala bentuk jihad fisik. } \\
\text { Ayat tersebut men-jelaskan: untuk } \\
\text { memerangi kaum Kafir, mulailah dengan } \\
\text { jihad pemikiran, sebab, senjata nalar, logika } \\
\text { dan argumentasi yang di-dasarkan pada } \\
\text { wahyu ilahi lebih efektif daripada pedang. }\end{array}$ \\
\hline 3 & $\begin{array}{l}\text { Syafruddin/Syukur } \\
\text { Nikmat } \\
\text { Kemerdekaan/2016 }\end{array}$ & $\begin{array}{l}\text { Mengingat perjuangan para pendahulu yang } \\
\text { telah berjuang me-ngorbankan jiwa dan } \\
\text { raganya untuk mendapatkan kemerdekaan, } \\
\text { maka sudah selayaknya kita sebagai generasi } \\
\text { penerus mensyukuri apa yang telah kita } \\
\text { nikmati sekarang ini. Kita tidak perlu lagi } \\
\text { mengangkat senjata untuk berperang, tak } \\
\text { perlu lagi mengucurkan darah atau } \\
\text { merelakan nyawa untuk kemerdekaan bangsa } \\
\text { ini. } \\
\text { Yang perlu kita lakukan adalah } \\
\text { mensyukurinya dengan cara mempersiapkan } \\
\text { generasi berikutnya dengan pendidikan yang } \\
\text { baik. Kita harus memilihkan anak-anak } \\
\text { sekolah yang baik. Yang utama jangan lupa } \\
\text { bekali pendidikan agama. Ketika agama } \\
\text { mereka tidak baik, keimanan mereka telah } \\
\text { tiada, maka tidak ada yang diharapkan dari } \\
\text { anak kita tersebut. Oleh karena itu, keimanan } \\
\text { dan keilmuan harus kita ajarkan kepada } \\
\text { mereka. Dengan ilmu pengetahuan dan } \\
\text { teknologi, kehidupan menjadi mudah, dan } \\
\text { dengan agama kehidupan akan menjadi } \\
\text { terarah. }\end{array}$ \\
\hline 4 & $\begin{array}{l}\text { Ichsan Yusuf/Hakikat } \\
\text { Pahlawan/2016 }\end{array}$ & $\begin{array}{l}\text { Negara Indonesia memang sudah merdeka } \\
\text { dan aman, tetapi melestarikan kemerdekaan, }\end{array}$ \\
\hline
\end{tabular}




\begin{tabular}{|c|c|c|}
\hline & & $\begin{array}{l}\text { menjaga kemerdekaan, mengisi kemerdekaan } \\
\text { tetap harus kita wujudkan. Saat ini bangsa } \\
\text { kita tengah diserang krisis moral yang } \\
\text { mengobrak abrik para penerus bangsa. Cara } \\
\text { mengatasi krisis ini bukan hanya dengan } \\
\text { pidato yang berapi-api, atau slogan-slogan } \\
\text { kosong. Berusaha mengajak dan } \\
\text { mengingatkan untuk kembali ke jalan yang } \\
\text { benar juga meru-pakan wujud sifat-sifat } \\
\text { kepah-lawanan. Hakikat pahlawan yang } \\
\text { sesungguhnya adalah mengendalikan diri kita } \\
\text { dari hawa nafsu yang bisa menyesatkan dan } \\
\text { merugikan diri kita, yang pada akhirnya } \\
\text { berdampak pada Negara. }\end{array}$ \\
\hline 5 & $\begin{array}{lr}\text { Ahmad } & \text { Zahro/ } \\
\text { Darurat } & \text { Demi } \\
\text { Martabat/2016 } & \end{array}$ & $\begin{array}{l}\text { Menengok sejarah Rasul yang berdakwah } \\
\text { selama } 23 \text { tahun yang penuh dengan } \\
\text { gangguan, maka kita sebagai Muslim juga } \\
\text { harus menyadari bahwa dalam berdakwah } \\
\text { tidak akan lepas dari gangguan. Untuk } \\
\text { menghadapi gangguan itu kita perlu menjaga } \\
\text { Ukhumwah Islamiyah yang merupakan } \\
\text { martabat, harga diri umat Islam. Karena } \\
\text { sesungguhnya orang-orang beriman itu } \\
\text { saudara, apapun organisasinya, mazhabnya, } \\
\text { ataupun alirannya. Jangan sampai sesama } \\
\text { saudara timbul rasa benci atau permusuhan } \\
\text { yang nantinya juga akan merusak martabat } \\
\text { umat Islam sendiri }\end{array}$ \\
\hline 6 & $\begin{array}{l}\text { Ahwan Mukarrom/ } \\
\text { Memperingati Tahun } \\
\text { Baru Hijriyah/2016 }\end{array}$ & $\begin{array}{l}\text { Momentum tahun baru hijriyah semestinya } \\
\text { dijadikan untuk semakin mempererat } \\
\text { persaudaraan antar-Muslim utamanya, belajar } \\
\text { dari keteladanan peristiwa hijrah Rasulullah } \\
\text { dahulu, Rasulullah membangun ukhumwah. } \\
\text { Rasulullah saat datang ke Yasrib, yang } \\
\text { dilakukan adalah pertama, membangun } \\
\text { masjid, sebagai tempat bertemunya umat } \\
\text { Islam, bukan semata-mata tempat salat. } \\
\text { Kemudian yang kedua, mempersatukan } \\
\text { antara kaum Muhajirin dan kaum Anshar. } \\
\text { Kaum Muhajirin adalah yang berhijrah dari } \\
\text { Makkah ke Madinah, mereka tidak } \\
\text { membawa harta, sehingga mereka miskin, } \\
\text { maka ketika Rasulullah dipersaudarakan, }\end{array}$ \\
\hline
\end{tabular}




\begin{tabular}{|c|c|c|}
\hline & & $\begin{array}{l}\text { maka kemiskinan itu terhindar. Selain itu } \\
\text { pada peristiwa hijrah Rasulullah } \\
\text { mempersaudarakan antara kaum Muhajirin } \\
\text { dengan kaum Anshor. Begitulah yang terjadi, } \\
\text { antara kaum Muhajirin dan Anshar terjadi } \\
\text { ukhuwah yang luar biasa. Sehingga } \\
\text { terciptalah kondisi sosial yang sangat } \\
\text { kondusif dalam masyarakat Islam. Inilah } \\
\text { yang seharusnya kita amalkan di momen } \\
\text { peringatan hijrahnya Rasulullah }\end{array}$ \\
\hline 7 & $\begin{array}{lr}\text { Abdus } & \text { Salam } \\
\text { Nawawi/ } & \text { Berakhlak } \\
\text { Mulia dan } & \text { Bersikap } \\
\text { Proporsional } / 2016\end{array}$ & $\begin{array}{l}\text { Imam al-Ghazali, menjelaskan pengertian } \\
\text { Taqwa dengan kalimat yang pendek, yakni al- } \\
\text { taqwā: husn al-khuluq (taqwa adalah akhlak } \\
\text { yang baik). Wa husn al-khuluq idyān al-wäjibāt } \\
\text { (dan akhlak yang baik itu adalah memenuhi } \\
\text { kewa-jiban-kewajiban), 'ibād al-Rahmàn } \\
\text { (orang yang menghamba kepada yang Maha } \\
\text { Rahman) adalah orang-orang yang akhlaknya } \\
\text { baik. Allah swt menegaskan bahwa kita } \\
\text { dijadikan oleh Allah sebagai ummah wasatā } \\
\text { (umat tengah), umat moderat yang tingkah } \\
\text { laku dan putusan-putusannya proporsional. } \\
\text { Adapun yang dimaksud dengan bertindak } \\
\text { proposional adalah ber-tindak untuk } \\
\text { kepentingan yang dibutuhkan saja, untuk } \\
\text { menyelesai-kan solusi. Jangan lebih, karena } \\
\text { kalau lebih akan menjadi tidak proporsional. }\end{array}$ \\
\hline 8 & $\begin{array}{l}\text { Syafiq A. Mughni/ } \\
\text { Mempertahankan } \\
\text { Karakter Bangsa/2017 }\end{array}$ & $\begin{array}{l}\text { Janganlah kamu bersikap ekstrem, berlebih- } \\
\text { lebihan dalam soal agama ini. Kita patuh } \\
\text { terhadap ajaran Allah, tetapi tidak ber- } \\
\text { lebihan, tidak ekstrem dan tidak bersikap } \\
\text { radikal. Inilah yang disebut dengan wasatiyah } \\
\text { dalam prinsip Islam. Kemudian kita juga } \\
\text { diberikan karakter sebagai bangsa yang } \\
\text { toleran, karena kemajemukan bangsa kita } \\
\text { yang terdiri dari berbagai suku bangsa, } \\
\text { berbagai macam bahasa di masyarakat, } \\
\text { berbagai macam keyakinan, yang semuanya } \\
\text { hidup di tengah masyarakat. Maka pedoman } \\
\text { kita ialah harus yakin atas kebenaran ajaran } \\
\text { agama kita, tetapi kita mentoleransi, } \\
\text { menghargai, mengakui bahwa mereka } \\
\text { berbeda pendapat dengan kita. Prinsip }\end{array}$ \\
\hline
\end{tabular}




\begin{tabular}{|c|c|c|}
\hline & & $\begin{array}{l}\text { tasämụ adalah prinsip yang sangat } \\
\text { fundamental, yakni prinsip sekalipun kita } \\
\text { yakin apa yang kita sendiri yakini, tetapi } \\
\text { marilah kita serahkan semuanya itu kepada } \\
\text { Allah swt dengan terus berdakwah. Maka } \\
\text { tasāmuh menjadi karakter bangsa yang harus } \\
\text { kita pertahan-kan. Kita yakin kebenaran } \\
\text { keyaki-nan kita, tetapi kita harus terus } \\
\text { berdakwah sambil kita menghargai mereka } \\
\text { yang berbeda pendapat }\end{array}$ \\
\hline 9 & $\begin{array}{lr}\text { Ali } & \text { Maschan } \\
\text { Musa/Mewujudkan } \\
\text { Masyarakat } & \text { Madani } \\
\text { dalam } & \text { Bingkai } \\
\text { NKRI/2017 } & \end{array}$ & $\begin{array}{l}\text { Gagasan masyarakat madani di Indonesia } \\
\text { sesungguhnya baru populer sekitar awal } \\
\text { tahun 90-an. Konsep masyarakat madani } \\
\text { awal-nya, sebenarnya mulai berkembang di } \\
\text { Barat. Istilah masyarakat madani sebenarnya } \\
\text { hanya salah satu diantara beberapa istilah } \\
\text { yang sering digunakan orang dalam } \\
\text { menerjemahkan kata civil society. Menurt } \\
\text { tokoh M. Ryaas Rasyid menyatakan } \\
\text { bahwa civil society dalam arti masyarakat yang } \\
\text { berbudaya berarti suatu masyarakat yang } \\
\text { saling menghargai nilai-nilai sosial } \\
\text { kemanusiaan. Ada juga yang mengartikan } \\
\text { sebagai masyarakat warga atau masyarakat } \\
\text { kewargaan, yang berarti bahwa masyarakat } \\
\text { adalah anggota dari kelompok sosial tertentu } \\
\text { yang salah satu ciri utamanya adalah otonom } \\
\text { terhadap Negara. Masyarakat madani } \\
\text { merupakan masyarakat harapan bagi umat } \\
\text { Islam, bukan sekadar masyarakat yang lebih } \\
\text { banyak mengeksploitasi simbol-simbol } \\
\text { Islam, melainkan masyarakat yang mampu } \\
\text { membawakan substansi Islam dalam setiap } \\
\text { gerak kehidupan masyarakat. Untuk itu } \\
\text { masyarakat Islam dituntut ikut berperan } \\
\text { dalam rangka mewujudkan masyarakat } \\
\text { madani tersebut, khususnya dalam bingkai } \\
\text { NKRI. }\end{array}$ \\
\hline 10 & $\begin{array}{l}\text { Ichsan Yusuf/Cinta } \\
\text { Tanah Air Bagian dari } \\
\text { Iman/2017 }\end{array}$ & $\begin{array}{l}\text { Pada dasarnya cinta tanah air adalah tabiat } \\
\text { manusia. Di mana ia dilahirkan maka di } \\
\text { sanalah kesejahteraannya berada. } \\
\text { Sebagaimana Rasulullah yang sangat } \\
\text { mencintai tanah airnya (Makkah dan }\end{array}$ \\
\hline
\end{tabular}




\begin{tabular}{|c|c|c|}
\hline & & $\begin{array}{l}\text { Madinah), maka seyogyanya kita sebagai } \\
\text { pengikut Nabi juga mencintai tanah air. } \\
\text { Namun demikian, mencintai tanah air tidak } \\
\text { hanya karena tabiat, tetapi juga lahir dari } \\
\text { bentuk keimanan kita. Karenanya, jika kita } \\
\text { mengaku diri sebagai orang yang beriman, } \\
\text { maka mencintai Indonesia sebagai tanah air } \\
\text { yang jelas-jelas penduduknya mayoritas } \\
\text { Muslim merupakan keniscayaan. Inilah } \\
\text { makna penting pernyataan bubb al-watan min } \\
\text { al-imān (Cinta tanah air sebagian dari iman). } \\
\text { Konsekuensinya adalah, jika ada upaya dari } \\
\text { pihak-pihak tertentu yang berupaya } \\
\text { merongrong keutuhan NKRI, maka kita } \\
\text { wajib untuk menentangnya sebagai bentuk } \\
\text { keimanan kita. Tentunya dalam hal ini harus } \\
\text { dengan cara-cara yang dibenarkan menurut } \\
\text { aturan yang ada karena kita hidup dalam } \\
\text { sebuah negara yang terikat dengan aturan } \\
\text { yang dibuat oleh Negara. }\end{array}$ \\
\hline 11 & $\begin{array}{l}\text { Ali } \\
\text { Mashuri/Persaudaraan } \\
\text { Seiman dan } \\
\text { Universal/2017 }\end{array}$ & $\begin{array}{l}\text { Islam hadir dengan banyak pilihan dalam } \\
\text { praktik ibadah, apalagi muamalah. Harus kita } \\
\text { sadari, bahwa semua amalan yang kita } \\
\text { lakukan semua mempunyai dalil, dasar, } \\
\text { sumber, dan gurunya sehingga berhak } \\
\text { merasa benar. Sehingga, tidak } \\
\text { mempersoalkan amaliyah fihak yang berbeda } \\
\text { dengan kita. Apalagi menyalahkan, } \\
\text { menganggap sesat, menganggap syirik da lain } \\
\text { sebagainya. Di sisi lain kita juga harus } \\
\text { mengakui bahwa mayoritas bangsa Indonesia } \\
\text { beragama Islam, tetapi mayoritas lemah } \\
\text { dalam hal ekonomi. Untuk membangkitkan } \\
\text { serta memperkuat ekonomi umat, kita bisa } \\
\text { mendukung lembaga perbankan syariah. } \\
\text { Dana masyarakat yang terkumpul di bank } \\
\text { syariah, disalurkan untuk membiayai usaha- } \\
\text { usaha umat, sehingga ekonomi umat bisa } \\
\text { diberdayakan dan kesejahteraannya secara } \\
\text { bertahap menjadi meningkat. Siapapun tidak } \\
\text { bisa menyangkal, bahwa bila umat Islam } \\
\text { bersatu mendukung dan memajukan bank- } \\
\text { bank syariah, maka insya Allah kemajuan }\end{array}$ \\
\hline
\end{tabular}




\begin{tabular}{|c|c|c|}
\hline & & $\begin{array}{l}\text { umat dan 'izz al-Isläm wa al-muslimin secara } \\
\text { bertahap bisa diraih kembali, tidak saja dalam } \\
\text { bidang ekonomi, tetapi juga dalam bidang- } \\
\text { bidang lainnya. Hadis dari Anas bin Malik } \\
\text { r.a.Rasulullah bersabda: là yu'minu aḅadukum } \\
\text { hattā yubibba li akhīh mā yubibbu li nafsih } \\
\text { (Tidaklah beriman sempurna salah seorang } \\
\text { di antara kalian sehingga ia mencintai } \\
\text { saudaranya, sebagaimana ia men-cintai } \\
\text { dirinya sendiri). HR Muttafaqun alaih. }\end{array}$ \\
\hline 12 & $\begin{array}{lr}\text { Abdul } & \text { Salam } \\
\text { Nawawi/ } & \text { Benarkan } \\
\text { Perbedaan } & \text { Membawa } \\
\text { Rahmah/2017 }\end{array}$ & $\begin{array}{l}\text { Sebagaimana dijelaskan dalam al-Quran } \\
\text { bahwa manusia diciptakan dari dua unsur } \\
\text { yang berbeda. Secara fisik, manusia berasal } \\
\text { dari tanah (lumpur hitam), secara ruhani, } \\
\text { manusia berasal dari Allah swt. Dan karena } \\
\text { dua unsur yang berbeda inilah manusia } \\
\text { disebut sebagai makhluk yang paling } \\
\text { sempurna. Sehingga dapat ditarik kesimpulan } \\
\text { bahwa perbedaan bukanlah masalah yang } \\
\text { harus dibesar-besarkan. Justru adanya } \\
\text { perbedaan adalah wujud rahmat Allah } \\
\text { kepada seluruh umat manusia. Satu sama lain } \\
\text { saling mengenal dan memahami dengan } \\
\text { perbedaan masing-masing, kemu-dian } \\
\text { menguatkan di berbagai sisi. Jadi, walaupun } \\
\text { sanad hadis ikhtiläf ummati rahmah tergolong } \\
\text { lemah, namun sebenarnya pluralitas } \\
\text { (keragaman) yang terjadi di seluruh dunia ini } \\
\text { merupakan rahmat dari Allah. Kalau kita } \\
\text { ingin mendapat rahmat dari pluralitas itu, } \\
\text { maka gunakanlah rahmat yang dipesankan } \\
\text { oleh Rasulullah. }\end{array}$ \\
\hline 13 & $\begin{array}{l}\text { Imam Haromain/ } \\
\text { Memerkokoh } \\
\text { Persatuan ala } \\
\text { Rasulullah/2017 }\end{array}$ & $\begin{array}{l}\text { Persatuan antara umat Islam dan ukhumwah } \\
\text { islamiyah merupakan salah satu prinsip yang } \\
\text { amat mendasar dalam agama kita. Persatuan } \\
\text { akan menghasilkan begitu banyak manfaat. } \\
\text { Persatuan akan membuahkan kekuatan, } \\
\text { persatuan akan menumbuhkan ketenangan } \\
\text { batin, persatuan akan memunculkan } \\
\text { solidaritas, persatuan akan membangun } \\
\text { kepedulian sosial, dan masih banyak buah } \\
\text { manis lain yang akan dihasilkan oleh } \\
\text { persatuan. Karenanya, begitu banyak ibadah }\end{array}$ \\
\hline
\end{tabular}




\begin{tabular}{|c|c|c|}
\hline & & $\begin{array}{l}\text { dalam agama kita yang disyariatkan untuk } \\
\text { dilaksanakan secara berjemaah. }\end{array}$ \\
\hline 14 & $\begin{array}{l}\text { Abdullah Sahab/Nilai } \\
\text { Rasulullah saw dalam } \\
\text { Sejarah Peradaban } \\
\text { Manusia/2018 }\end{array}$ & $\begin{array}{l}\text { Rasulullah adalah sosok teladan yang ideal } \\
\text { bagi umat Islam di mana pun. Sampai- } \\
\text { sampai ada seorang penulis non-Muslim } \\
\text { yang mengatakan bahwa Nabi Muhammad } \\
\text { dalam sejarah perkembangan manusia } \\
\text { diletakkan nomor satu dalam buku Seratus } \\
\text { Tokoh yang Berpengaruh di Dunia, karena } \\
\text { berpegang pada keyakinan, bahwa Nabi } \\
\text { Muhammad adalah satu-satunya manusia } \\
\text { dalam sejarah yang berhasil meraih } \\
\text { kesuksesan luar biasa, baik ditilik dari ukuran } \\
\text { agama maupun ruang lingkup duniawi. } \\
\text { Bayangkan, kalau seseorang datang dalam } \\
\text { sejarah kemanusiaan, misalnya seorang } \\
\text { ilmuwan atau filsuf, yang mereka unggulkan } \\
\text { hanya satu bidang saja. Misalnya hanya } \\
\text { unggul dalam bidang ilmu pengetahuan, } \\
\text { dalam bidang politik, dalam bidang militer. } \\
\text { Sebaliknya, Rasulullah saw unggul di semua } \\
\text { bidang, beliau seorang orator, psikolog, } \\
\text { ilmuwan, politik, militer, dan seorang yang } \\
\text { taqwa kepada Allah swt. Beliau mencintai } \\
\text { keluarganya, mencintai sahabatnya dan } \\
\text { semua orang. Itulah yang bisa dan ingin } \\
\text { ditauladani oleh siapa pun pada diri } \\
\text { Rasululah. }\end{array}$ \\
\hline 15 & $\begin{array}{l}\text { Ma'ruf } \\
\text { Khozin/Memupuk } \\
\text { Persaudaraan Sesama } \\
\text { Muslim/2018 }\end{array}$ & 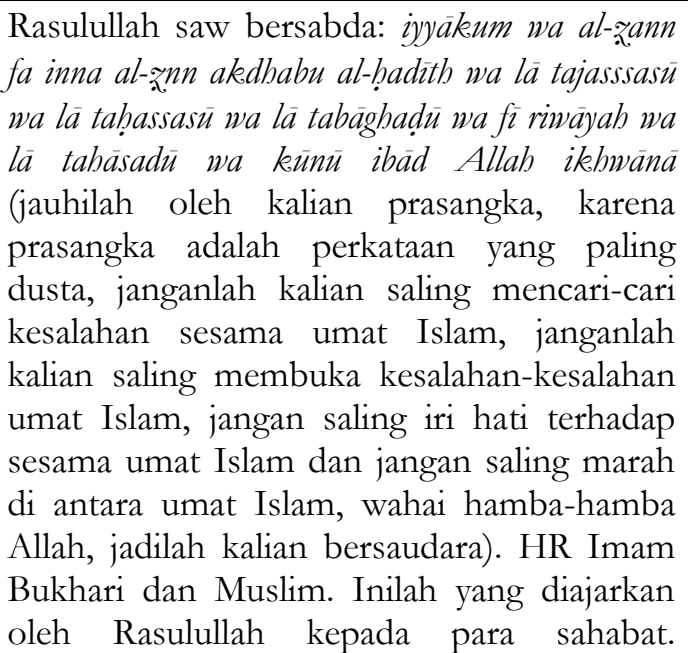 \\
\hline
\end{tabular}




\begin{tabular}{|c|c|c|}
\hline & & $\begin{array}{l}\text { Ternyata, apa yang dilakukan oleh Rasulullah } \\
\text { memperkuat yang satu dengan yang lain, } \\
\text { karena beliau para sahabat, tabiin, dan ulama, } \\
\text { dalam hatinya tidak memiliki penyakit hati. } \\
\text { Mereka dijauhkan dari prasangka buruk } \\
\text { kepada sesama saudaranya. Ternyata, untuk } \\
\text { menjadi Muslim yang bisa bersaudara } \\
\text { dengan indah, sebenarnya hanya cukup dua } \\
\text { modal. Pertama, perbaiki hati kita untuk } \\
\text { berprasangka baik kepada sesama muslim. } \\
\text { Kedua, hilangkan perdebatan kita dengan } \\
\text { sesama Muslim. Tidak merasa paling sunnah, } \\
\text { yang merasa paling sesuai dengan Nabi, tidak } \\
\text { merasa paling sesuai dengan tuntunan Nabi, } \\
\text { sebab ulama kita melakukan amalan juga } \\
\text { berdasarkan al-Qur'ān dan hadis. }\end{array}$ \\
\hline 16 & $\begin{array}{l}\text { Ahwan Mukarrom/ } \\
\text { Perbedaan dalam } \\
\text { Bingkai } \\
\text { Ukhuwwah/2018 }\end{array}$ & $\begin{array}{l}\text { Indonesia beberapa hari yang lalu mengalami } \\
\text { bencana. Belum kering air mata ini mengalir } \\
\text { karena bencana Lombok, kini air mata kita } \\
\text { kembali terkuras saat mendengar berita } \\
\text { gempa dan tsunami yang terjadi di Palu dan } \\
\text { Donggala. Oleh karenanya, sangat tidak } \\
\text { bijaksana jika kita mengatakan bahwa } \\
\text { bencana yang menimpa mereka adalah } \\
\text { karena dosa-dosa mereka, sehingga Allah } \\
\text { menurunkan azab. Akan lebih bijak jika } \\
\text { dikatakan bahwa apa yang menimpa mereka } \\
\text { adalah ujian dari Allah untuk melihat hamba- } \\
\text { hambanya yang sabar. Kebijaksanaan sangat } \\
\text { penting untuk menjaga persaudaraan dan } \\
\text { persatuan dalam setiap perbedaan yang ada. }\end{array}$ \\
\hline
\end{tabular}

Melihat potret tema dan materi khotbah yang disampaikan para khatib MAS di atas, bagi penulis, tergambar begitu jelas terjadinya penguatan moderasi agama (Islam) dalam bingkai Negara Kesatuan Republik Indonesia (NKRI). Sebab, umat Islam menyadari adanya ancaman dan gangguan perpecahan yang datang dari berbagai penjuru dengan segala strategi dan modusnya. Oleh sebab itu perbedaan ras, suku, agama, dan aliran dalam agama harus memerkaya dan sekaligus menjadi alat perekat di dalam kehidupan berbangsa dalam bingkai persatuan, bukan malah sebaliknya menjadi pemicu perpecahan. Tidak perlu mempertajam perbedaan yang bersifat furü íyah, karena bukan hal yang prinsip. Yang dikedepankan adalah saling menghargai dan 
menghormati perbedaan yang ada, tidak memaksakan pendapat sendiri. Sebab merajut persaudaraan sesama Muslim adalah kewajiban bersama, apapun organisasinya, mazhabnya, dan alirannya. Jangan sampai sesama Muslim timbul rasa benci dan permusuhan, yang akan merusak martabat Islam itu sendiri.

Umat Islam dijadikan Allah sebagai umat wasatā (moderat) yang tingkah laku dan putusan-putusannya proporsional. Maksud proposional adalah bertindak untuk kepentingan yang dibutuhkan saja, untuk mencari solusi dan menyelesaikan problematika keagamaan dan kemasyarakatan. Jangan berlebihan, karena berlebihan berarti tidak proporsional. Umat Islam patuh terhadap ajaran Allah, tetapi tidak berlebihan, tidak ekstrem dan tidak bersikap radikal dan liberal. Inilah yang disebut dengan wasatìyah (asas pertengahan) dalam prinsip Islam. Kemudian berkarakter sebagai bangsa yang toleran, karena kemajemukan bangsa Indonesia yang terdiri dari berbagai suku, berbagai macam bahasa, berbagai macam keyakinan, yang semuanya hidup di tengah-tengah masyarakat. Pedoman Muslim adalah yakin atas kebenaran ajaran agamanya, sekaligus mentoleransi, menghargai, mengakui segenap perbedaan yang ada di dunia ini.

Prinsip tasāmụ̧ adalah prinsip yang sangat fundamental untuk merajut persatuan. Prinsip ini menjadi karakter bangsa yang tidak berarti mengahalalkan segala cara. Tasämuh hanya berada di wilayah sosiologis, bukan teologis. Sebab wilayah teologis umat Muslim mempunyai batasan sebagaimana yang tertuang dalam al-Qur'ān, lakum dinukum wa liya din. ${ }^{36}$

\section{Dinamika Pengarusutamaan Moderasi Islam di Masjid Nasional Al-Akbar Surabaya (MAS)}

Dinamika adalah sesuatu yang mengandung arti tenaga kekuatan, selalu bergerak, berkembang dan dapat menyesuaikan diri secara memadai terhadap keadaan. Dinamika juga berarti adanya interaksi dan interdepensi antara anggota kelompok dengan kelompok secara keseluruhan.

Dinamika dalam pengarusutamaan Islam Moderat di MAS berarti terjadinya interaksi dan interdepensi antara orang atau sekelompok orang-dalam hal ini pengelola MAS, dan pihak yang berkepentingan—dalam upayanya mengawal Islam Moderat di MAS.

\footnotetext{
36 Roem Rowi (Imam Besar/Mantan Direktur Imarah Masjid Nasional al-Akbar Surabaya), Wawancara, Surabaya 12 Maret 2017.
} 
Dalam praktik ibadah di MAS memilih corak, warna, dan model pelaksanaan ibadah yang diamalkan oleh mayoritas Nahdiyyin. Model ini dipilih sebagai representasi amalan mayoritas jemaah. Berikut pernyataan pengelola MAS.

"MAS dalam amaliahnya seperti salat subuh dan qunut, zikir jahr bakda salat maktübah, dan sebagainya mengamalkan tradisi Naḥdhiyyin. Tradisi ini dipilih dan ditetapkan tentunya berdasarkan beberapa pertimbangan. MAS memilih model ini untuk mengakomodasi dan sebagai representasi dari amaliyah mayoritas masyarakat surabaya dan Jawa Timur pada umumnya. Tetapi bukan berarti MAS adalah menjadi masjid NU. Sama halnya dengan Masjid Al-Falah Surabaya atau Masjid Nurul Iman Margorejo Indah, Masjid Al-Wahyu umpamanya atau beberapa masjid lainnya, yang secara amaliah haliyahnya seperti tradisi Muhammadiyah (salat subuh tanpa qunüt, tanpa zikir jahr, bacaan fatihah tanpa basmalah dan sebagainya), tetapi Masjid Al-Falah dan lain-lainnya itu tidak bisa dan atau tidak mau disebut sebagai Masjid Muhammadiyah, tetapi masjidnya umat Islam. Sama halnya dengan MAS sebagai masjid umat Islam, tentu tak ada larangan bagi berbagai aliran dan mazhab, tetapi model yang ditetapkan adalah amaliyah tradisi umat mayoritas. Jadi, konstruksi rumah MAS moderatismenya adalah seperti itu". ${ }^{37}$

Demikian pula dalam pelaksanaan salat Jumat. Semula salat Jumat di MAS dilakukan dengan dua azan dan memakai tongkat. Tetapi kemudian dalam praktik pelaksanaannya tidak selalu dipraktikkan seperti itu, karena para khatib tidak seluruhnya berasal dari komunitas Nahdhiyyin, tetapi juga dari kalangan Muhammdiyah, yang tradisi Jumatannya tidak pakai dua azan dan pegang tongkat. Sehingga di dalam praktik pelaksanan salat Jumat bersifat fleksibel sesuai dengan selera khatib sendiri. Hal ini diuangkapkan oleh Abdusshomad Bukhori berikut.

"Dulu kebijakan awal penyelenggaraan ibadah, seperti salat Jumat, MAS dilaksanakan dengan dua azan, mengikuti ijtihad sahabat Usman, dan menggunakan tongkat, kecuali yang minta tidak pakai tongkat. Akan tetapi akhir-akhir ini kenapa berubah tradisi itu

37 Kholiq Idris (Kepala Bidang Ibadah Masjid Nasional al-Akbar Surabaya), Wawancara, Surabaya, 15 Februari 2017. 
menjadi seakan-akan terbalik, yakni khotbah Jumat tidak pakai tongkat, kecuali yang minta pakai tongkat". ${ }^{38}$

Pernyataan Bukhori di atas mengisyaratkan adanya dinamika pelaksanaan dan praktik ibadah yang dilaksanakan oleh MAS dari waktu ke waktu, disebabkan adanya selera dan kecendrungan dari pengelola MAS dan jemaah untuk mengakomodir selera tersebut. Hal ini terjadi terus menerus dari periode ke periode dan dari pengelola ke pengelola penggantinya. Hal ini diungkapkan Sumarkan, Direktur Ibadah MAS sebagai berikut.

"Akhir-akhir ini pelaksanaan ibadah salat Jumat dikembalikan lagi seperti pada semula, karena memperhatikan keinginan tradisi amalan mayoritas (Nahdhiyyin), yaitu khotbah Jumat dengan dua azan dan memakai tongkat, kecuali bagi yang minta tidak pakai." ${ }^{\prime 39}$

Demikian pula dengan amalan zikir habis salat Jumat KH Bashori Ali menganjurkan wirid/zikir dengan membaca surat al-Ikhlāṣ, alFalaq, dan al-Nās masing-masing sejumlah tujuh kali, kemudian Roem Rowi meminta kepada beliau agar amalan itu tidak ditradisikan di MAS, karena amalan itu sandarannya pada riwayat hadis yang lemah. Pada saat itu Roem Rowi menulis surat keberatannya kepada $\mathrm{KH}$ Bashori Alwi, yang kemudian dibalas oleh beliau dengan membuat buku kecil sebagai jawaban atas protes Roem Rowi tersebut. ${ }^{40}$

Selanjutnya tentang pelaksanaan salat tarawih dan witir yang dilaksanakan di MAS. Secara umum sebagai arah dan kebijakan ibadah yang diterapkan masjid ini adalah berkiblat ke Masjidil Haram, sebagaimana diamanatkan pada piagam MAS, yakni khusus dalam penyelenggaraan kegiatan ibadah salat berkiblat pada penyelenggaraan di Masjidil Haram Mekah. Mekah melaksanakan salat tarawih dan witir 23 rakaat. Salat tarawih di MAS ini dilaksanakan 20 rakaat dan dipimpin oleh dua imam. Salat witir tiga rakaat dengan dua kali salam atau sekali salam, tergantung pada imam. Pada saat itu dapat kita saksikan bahwa salat witir di Masjidil Haram hanya dilaksanakan dengan tiga rakaat satu salam. Tetapi beberapa tahun terakhir ini di Mekkah pun melaksanakan salat witir dengan dua kali salam.

\footnotetext{
38 Abdusshomad Bukhori (Mantan Direktur Ibadah Imaroh Masjid Nasional alAkbar Surabaya/Ketua MUI Jawa Timur/Imam Besar Masjid Nasional al-Akbar Surabaya), Wawancara, Surabaya 1 Februari 2017.

39 Sumarkan (Direktur Ibadah Masjid Nasional al-Akbar Surabaya), Wawancara, Surabaya, 2 Februari 2017.

40 Kholiq Idris (Kepala Bidang Ibadah Masjid Nasional al-Akbar Surabaya), Wawancara, Surabaya 28 Februari 2017.
} 
Beberapa strategi dilakukan oleh MAS dalam melakukan monitoring dan evaluasi terhadap pelaksanaan ibadah baaliyah, kemudian melakukan langkah-langkah mencari solusi dan model yang sesuai dan dapat diterima jemaah.

"Sekurang-kurangnya setiap tahun sekali bidang dakwah mengadakan rapat dengan para imam dan muazin MAS. Rapat tersebut dilaksanakan untuk mengevaluasi pelaksanaan ibadah di MAS, khususnya menjelang Ramadan. Forum ini dilakukan untuk memperhatikan masukan, kritik dan saran dari jemaah. Selanjutnya mengambil langkah-langkah yang perlu untuk kepentingan Jemaah". ${ }^{41}$

Demikian pula untuk materi kajian yang dilaksanakan oleh MAS terdapat kebijakan yang telah diatur, yaitu dengan berkembangnya aliran liberalisme, fundamentalisme, radikalisme, dan Shí'ah, tidak boleh disebarkan di MAS, kecuali sebagai pencerahan dengan memperkenalkan aliran-aliran yang terjadi di lintasan sejarah tanpa menggiring pada ideologi tertentu. ${ }^{42}$

Untuk kajian di bidang ilmu tauhid/kalam/teologi kebijakan imam besar (Abdusshomad Buchori) selalu menyatakan bahwa liberalisme, fundamentalisme, radikalisme dan Shī'ah adalah paham yang dilarang. Buchori sebagai ketua MUI Propinsi Jatim merasa berkewajiban mengawal fatwa-fatwa MUI. ${ }^{43}$ Oleh karenanya disediakan waktu khusus untuk kajian Fatwa MUI ini di MAS. Pahampaham tersebut adalah dilarang di MAS. MAS berusaha memfilter pemikiran paham-paham tersebut untuk diajarkan di MAS. Sebaliknya, yang harus disemaikan adalah Islam Moderat dengan landasan teologi Ash'ariyah dan fiqih salah satu mazhab yang empat (Mālikīyah, Hanafìyah, Hanābilah, dan Shāfi'īyah).

Sering pula pengelola MAS mengganti khatib/penceramah pada even-even tertentu, karena menyesuaikan dengan momennya dan adanya kekhawatiran akan materi khotbah/ceramah, atau karena sempitnya waktu yang tersedia disebabkan datangnya tamu penting seperti presiden dan sebagainya. MAS harus mengontrol dan mengatur sesuai dengan permintaan protokolernya. Pernah terjadi

\footnotetext{
41 Ahmad Zahro (Imam Besar/Mantan Kepala Bidang Masjid Nasional al-Akbar Surabaya), Wawancara, Surabaya, 10 Desember 2017.

42 Sumarkan (Direktur Ibadah Masjid Nasional al-Akbar Surabaya), Wawancara, 04 Maret 2017.

43 Lihat fatwa MUI tentang Pluralisme, Liberalisme dan Sekularisme (Surabaya: Majelis Ulama Indonesia Provinsi Jawa Timur, 2007).
} 
kunjungan presiden ke Jawa Timur pada hari Jumat. Beliau berkenan untuk salat Jumat di MAS. Sementara sesuai jadwal yang menjadi khatib adalah Mr X (sebagai imam besar MAS dan ketua MUI Provinsi Jawa Timur). Secara protokoler tamu penting seperti presiden menjadi tanggungan Pemprov untuk mengaturnya. Karena Pemprov sangat mengenal gaya, karakter, dan performa dakwahnya, maka Pemprov meminta agar khatibnya diganti dengan Mr. Y.

"Ketika Presiden Jokowi berkunjung dan salat Jumat di MAS. Pada waktu itu yang terjadwal sebagai khatib adalah Mr X. Karena Pemprov khawatir akan kebiasaan beliau yang sulit mengendalikan waktu dan mungkin juga materi khotbahnya, maka Pemprov minta diganti dengan Mr Y. Sesungguhnya MAS agak kesulitan untuk mengganti beliau, atas alasan apa, mengingat beliau adalah imam besar MAS dan ketua MUI Jatim. Akhirnya, MAS memenuhi permintaan Pemprov tersebut." ${ }^{\text {44 }}$

Artinya, pengawalan dan pengontrolan MAS terhadap setiap even khotbah dan ceramah sangat ketat, itu dilakukan didalam rangka mengantisipasi terjadinya hal-hal yang tidak diinginkan. MAS sering mendapatkan kunjungan kehormatan beberapa imam dan khatib dari beberapa negara Timur Tengah seperti imam Masjidil Haram Mekkah, Masjid Nabawi Madinah, Iran, Palestina, Suriah dan sebagainya. Walau demikian MAS tetap selektif terhadap mereka, oleh karenanya sebagian dari mereka bisa diterima, tetapi sebagiannya juga ditolak.

"Dulu pernah imam senior Masjidil Haram Abdurrahman Shudais dan Suraim menjadi imam/khatib di MAS. Tetapi tidak seluruh tamu boleh jadi imam/khatib, MAS memiliki beberapa pertimbangan. Sebab imam/khatib dari Timur Tengah banyak alokasi waktu, yakni khotbah dalam bahasa Arab dan setelah salat Jumat dilanjutkan dengan penjelasan". ${ }^{45}$

Tidak semua orang bisa diterima untuk menjadi imam/khatib di MAS. Beberapa kali MAS tak meloloskan tawaran imam/khatib dari luar yang terjadwal. MAS harus mempertimbangkan betul-betul khatib/dai yang diloloskan untuk menghindari kemungkinan ekses keresahan jemaah.

\footnotetext{
44 Sumarkan (Direktur Ibadah Masjid Nasional al-Akbar Surabaya), Wawancara, Surabaya 14 Desember 2017.

45 Kholiq Idris (Kepala Bidang Ibadah Masjid Nasional al-Akbar Surabaya), Wawancara, Surabaya 10 Maret 2017.
} 


\section{Penutup}

Konstruksi Islam Moderat di Masjid Nasional Al-Akbar Surabaya (MAS) adalah Islam rạ̣mah li al-älamin dengan mengusung dan menjunjung lima prinsip dasar, yaitu: tawäsut, tawāaun ta'ädul, tasāmuh, dan ber-amr ma'rüf wa naby 'an al-munkar bi al-ma'rüf.

Bagi kalangan khatib/dai MAS, Islam moderat adalah Islam yang selama ini menjadi perhatian mereka. Begitupun dalam hal keragaman, mereka lebih memilih bersikap moderat dari pada condong terhadap salah satu aliran ekstrem tertentu, baik terhadap aliran ekstrem kiri dan ekstrem kanan. Dalam pandangan mereka, moderatisme adalah wujud ideal keberislaman sesungguhnya. Moderatisme memiliki penghargaan dan penghormatan cukup besar terhadap perbedaan, namun pada saat bersamaan mereka senantiasa mawas diri, menjaga jarak untuk tidak meleburkan dirinya pada keyakinan-keyakinan lain di luar dirinya. Moderatisme inilah yang setiap hari mereka tanamkan ke dalam tradisi keislaman di lingkungan MAS. Satu karakteristik berislam yang sangat menghargai perbedaan adalah menjunjung tinggi sopan santun, menebarkan kasih sayang, dan menebarkan nilai-nilai keluhuran. Dalam keyakinan mereka, hanya dengan cara-cara keberislaman seperti inilah, cita-cita besar Islam sebagai rabmab li al'ālamin dapat terwujud.

Dinamika pengarusutamaan Islam Moderat yang dilakukan oleh MAS adalah dengan strategi mengawal dakwah mulai dari memilih khotib/dai, menentukan tema-tema Islam rabmah li al-älamin, dengan menjunjung tinggi al-akhlāq al-karimah sesuai visi, misi dan nilai MAS dengan mengedepankan amānah, istiqämah, uswah, mas'üliyah, dan li jamī al-ummah). Tipologi Islam Moderat MAS adalah TradisionalisModernis bercorak Islam Nusantara Berkemajuan.

\section{Daftar Rujukan}

al-Makassari, Ridwan dan Gaus, Ahmad (eds.). Benib-benih Islam Radikal di Masjid: Studi Kasus Jakarta dan Solo. Jakarta: Center for the Study or Religion and Culture (SSRC) UIN Syarif Hidayatullah Jakarta, 2010.

Baidhawy, Zakiyuddin. "Muatan Nilai-nilai Multikultural dan AntiMultikultural dari Mimbar Masjid di Kota Solo: Multiculturalism and Antimulticulturalism from Pulpits of Mosques", Jurnal Analisa, Vol. 21, No. 2, Desember 2014. 
Bukhori, Abdusshomad (Mantan Direktur Ibadah Imaroh Masjid Nasional al-Akbar Surabaya/Ketua MUI Jawa Timur/Imam Besar Masjid Nasional al-Akbar Surabaya). Wawancara. Surabaya 1 Februari 2017.

Hendro (Direktur Utama Masjid Nasional al-Akbar Surabaya). Wawancara. Surabaya 01 Desember 2017.

Idris, Kholiq (Kepala Bidang Ibadah Masjid Nasional al-Akbar Surabaya). Wawancara. Surabaya 5 Februari 2017.

----. Wawancara. Surabaya, 15 Februari 2017.

----. Wawancara. Surabaya 28 Februari 2017.

-----. Wawancara. 10 Maret 2017.

Mubarok, Agus. Problematika Masjid dan Solusinya. Bandung: Emqies Publishing, 2017.

Noer, Helmi M. (Kepala Bidang Hubungan Masyarakat Masjid Nasional al-Akbar Surabaya). Wawancara. Surabaya 3 Desember 2017.

Rowi, Roem (Imam Besar/Mantan Direktur Imarah Masjid Nasional al-Akbar Surabaya). Wawancara. Surabaya 03 Maret 2017.

-----. Wawancara. Surabaya 12 Maret 2017.

----. Wawancara. Surabaya 12 Maret 2017.

Roziqi, Muhammad (Direktur Imarah Ijtimaiyah Masjid Nasional AlAkbar 2012-2016, Ketua PWDMI Jawa Timur Periode 20132017). Wawancara. Surabaya, 14 Desember 2017.

Sambutan Gubernur Jawa Timur, Soekarwo, 16 Tabun Masjid Nasional Al Akbar Surabaya (10 November 2000-2010). Surabaya: Al Akbar, 2016.

Siswantoro, Endro (Direktur Utama Masjid Nasional al-Akbar Surabaya). Wawancara. 2 Desember 2017.

Sumarkan (Direktur Ibadah Masjid Nasional al-Akbar Surabaya). Wawancara. Surabaya 04 Maret 2017. ----. Wawancara. Surabaya, 2 Februari 2017.

-----. Wawancara. Surabaya 04 Maret 2017.

----. Wawancara. Surabaya 14 Desember 2017.

Yani, Ahmad. Mencintai Masjid. Jakarta: Pustaka Harum, 2002.

Zada, Khamami. "Wajah Radikal Penerbitan Islam di Indonesia", Indo-Islamika, Vol. 1, No. 1 (2011.

Zahro, Ahmad (Imam Besar/Mantan Kepala Bidang Masjid Nasional al-Akbar Surabaya). Wawancara. Surabaya, 10 Desember 2017. 
Zulkifli, Muhammad. "Peran Organisasi Remaja Masjid DKI Jakarta dalam Deradikalisasi: Studi Kasus Remaja Islam Cut Meutia (RICMA) dan Remaja Islam Sunda Kelapa (RISKA)”. TesisUniversitas Indonesia, 2014. 